\title{
DASAR GENETIK OBESITAS VISERAL
}

\author{
Muhammad Rasjad Indra \\ Laboratorium Fisiologi Fakultas Kedokteran Universitas Brawijaya Malang
}

\begin{abstract}
Obesity is defined as an excess proportion of total body fat. Nearly 40 million adults in the United States can be defined as obese. There are several indexes used to assess obesity. The most common measure of obesity is the body mass index (BMI). Obesity occurs when a person's calorie intake exceeds the amount of energy he or she burns. Obesity tends to run in families, suggesting that it may have a genetic cause. However, family members share not only genes but also diet and lifestyle habits that may contribute to obesity. Separating these lifestyle factors from genetic ones is often difficult. Still, growing evidence points to heredity as a strong determining factor of obesity. In one study of adults who were adopted as children, researchers found that their subjects' adult weights were closer to their biological parents' weights than to their adoptive parents'. The environment provided by the adoptive family apparently had less influence on the development of obesity than the person's genetic makeup. Although genes are an important factor in many cases of obesity, a person's environment also plays a significant part. Psychological factors may also influence eating habits. Many people eat in response to negative emotions such as boredom, sadness, or anger.
\end{abstract}

Key words: Genetic, Obesity, visceral

\section{PENDAHULUAN}

Obesitas pada hakekatnya merupakan timbunan triasilgliserol berlebih pada jaringan lemak akibat asupan energi berlebih dibanding penggunaannya. Pada tingkat berat obesitas terutama didasari faktor genetik yang kemungkinan poligenik. Hipotesis thrifty gene menjelaskan bahwa kehidupan modern yang ditandai asupan energi tinggi dan penurunan aktifitas fisik memang memberi keuntungan pada variasi genetik. Di sisi lain, konsekuensi fisik obesitas (misalnya arthritis) sangat mengganggu dan merugikan. Dampak metabolik obesitas mengarah pada terjadinya resistansi insulin, diabetes mellitus, perlemakan hepar, penyakit jantung koroner, hipertensi dan sindroma polikistik ovarium (1). Patofisiologi penyakit-penyakit tersebut mungkin merupakan kombinasi efek toksik asam lemak bebas dan adipokin (beberapa sitokin yang dihasilkan jaringan adiposa) (1).

Definisi yang lengkap dan tepat tentang mekanisme molekular fisiologi pengendalian massa lemak tubuh dan patogenesis obesitas sangat dibutuhkan untuk mendasari penatalaksanaan pencegahan dan terapi obesitas yang rasional. Respons tubuh terhadap asupan makanan dan faktor lingkungan lain sangat bervariasi tergantung karakter sistem pengendali berat badan. Karakter sistem pengendali berat badan dalam merespons asupan makanan tergantung pada struktur dan fungsi genetik yang melatar belakangi (2)

Jurnal Kedokteran Brawijaya, Vol. XXII, No.1, April 2006

Korespondensi: M. Rasjad Indra; Laboratorium Fisiologi Fakultas Kedokteran Unibraw; Jl. Veteran Malang 65145; Telp. (0341) 580993 ext. 115
Pengetahuan tentang gen dan molekul yang berperan dalam proses biokimiawi dan proses lain yang berdampak pada terjadinya obesitas meningkatkan pemahaman molekuler sistem pengendali berat badan dan membuka jalan metode baru pengendalian obesitas, baik secara farmakologis maupun intervensi nutrisional, bahkan mungkin juga genetik.

\section{Definisi Obesitas}

WHO 1985 mendefinisikan obesitas sebagai kondisi BMI $>30$ untuk laki-laki dan $>28,6$ untuk perempuan. Definisi tersebut kemudian dikembangkan dengan $\mathrm{BMI}>25$ untuk berat badan lebih over weight dan BMI $>30$ sebagai obese. Obesitas telah mewabah ke seluruh dunia dan prevalensinya bervariasi antar negara. Beberapa penelitian melaporkan terjadinya peningkatan prevalensi pada anak (3). Variasi prevalensi obesitas antar negara dan waktu menunjukkan bahwa faktor lingkungan merupakan faktor dominan terjadinya obesitas (4).

Obesitas terjadi bila asupan energi melebihi penggunaannya sebagai akibat perubahan genetik maupun lingkungan. Proses biokimiawi dalam tubuh menentukan rasa kenyang dan lapar, termasuk pemilihan macam makanan, selera dan frekuensi makan seseorang. Kondisi dan aktifitas menyimpan kelebihan energi di jaringan adiposit dikomunikasikan ke sistem saraf sentral melalui mediator leptin dan sinyal-sinyal lain (4). 


\section{Faktor Genetik Obesitas}

Pendapat bahwa beberapa individu dilahirkan dengan kecenderungan obese bukanlah hal baru. Hipocrates menyatakan bahwa kematian mendadak lebih sering terjadi pada individu yang secara alami tubuhnya berlemak daripada yang kurus. Berdasarkan hipotesis thrifty gene, populasi tertentu memiliki gen yang menentukan peningkatan simpanan lemak tubuh yang dibutuhkan untuk cadangan, tetapi pada jaman modern ini justru menjurus pada timbulnya obesitas dan diabetes mellitus tipe 2 . Identifikasi kandidat thrifty gene dapat membantu pemahaman patogenesis beberapa penyakit yang dimediasi oleh pengurangan aktifitas fisik (5).

Perubahan bayi dengan berat badan kurang menjadi anak dengan berat badan lebih dan kemudian menjadi individu obese pada dewasa merupakan proses alami yang mengundang pertanyaan. Ada dugaan bahwa massa lemak dan sensitifitas insulin ditetapkan secara genetik dan metabolik selama dalam kandungan (Baker Hypothesis) (6).

Faktor lingkungan dan asupan makanan memiliki peranan penting pada terjadinya obesitas. Penelitian pada individu kembar menunjukkan peran penting gen dalam menentukan indeks massa tubuh (BMI) (7). Di samping mengendalikan massa lemak, gen juga mengatur distribusi jaringan lemak tubuh dan peran gen dalam pemunculan sifat yang berkaitan dengan obesitas mencapai $50 \%$ bahkan lebih (8). Banyak gen yang telah diketahui menentukan terjadinya obesitas. Telah ditemukan lebih dari 300 gen, marker dan kromosom yang erat kaitannya dengan obesitas (9). Evolusi temuan gen dan marker yang berkaitan dengan obesitas sangat cepat, dari hanya 24 pada tahun 1994 menjadi 384 pada tahun 2002 (Tabel 1).

Tabel 1. Perkembangan temuan jumlah gen dan petanda yang berkaitan dengan fenotip obesitas pada manusia

\begin{tabular}{cc}
\hline Tahun & $\mathbf{n}$ \\
\hline 1994 & 24 \\
\hline 1995 & 31 \\
\hline 1996 & 50 \\
\hline 1997 & 97 \\
\hline 1998 & 126 \\
\hline 1999 & 178 \\
\hline 2000 & 214 \\
\hline 2001 & 287 \\
\hline 2002 & 384 \\
\hline
\end{tabular}

Meskipun telah ditemukan ratusan lokus berkaitan dengan obesitas, hanya beberapa saja yang dapat dijelaskan kaitannya, antara lain 1p36 (D1S468 gen reseptor TNF alpha), 2q14 (D2S410 gen berkaitan dengan hipertrigliserida) dan $6 \mathrm{q} 27$ (lokus berkaitan dengan transient neonatal diabetes mellitus)(10). Di sisi lain, penelitian terus dilakukan untuk mengungkap adanya mutasi gen yang diperkirakan berhubungan dengan obesitas. Mekanisme terjadinya obesitas pada dasarnya merupakan akibat faktor genetik atau lingkungan dalam hal :

\section{Pengendalian Asupan Makanan}

Pengendalian asupan makanan melibatkan proses biokimiawi yang menentukan rasa lapar dan kenyang termasuk penentuan selera jenis makanan, nafsu makan dan frekuensi makannya. Besar dan aktifitas penyimpanan energi, terutama di jaringan lemak dikomunikasikan ke sistem saraf pusat melalui mediator leptin dan sinyal transduksi lain. Tampaknya, alur leptin merupakan regulator terpenting dalam keseimbangan energi tubuh. Mutasi gengen penyandi leptin dan sinyal transduksi tersebut akan mempengaruhi pengendali asupan makanan dan menjurus ke timbulnya obesitas (11).

Leptin disekresi adiposit ke sirkulasi dan ditranspor ke sistem saraf pusat untuk berikatan dengan reseptor leptin di nukleus arkuatus hipotalamus. Ikatan ini merangsang sintesis pro-opiomelanokortin (POMC). Dua zat yang dihasilkan dari POMC adalah alpha-melanocyte stimulating hormone (a-MSH) dan adrenocorticotrophine (ACTH). Alpha-MSH selanjutnya berikatan dengan reseptor melanokortin-4 (MC4-R) di nukleus paraventrikular hipotalamus yang akan menyebabkan penurunan asupan makanan (11).

Secara genetik, kadar leptin individu kurus akan meningkat dan cukup untuk menghentikan pertambahan badan setelah ada kenaikan berat badan 7 sampai $8 \mathrm{~kg}$. Individu yang kenaikan berat badannya melebih batas tersebut berarti tidak merespons leptin karena hormon tersebut tidak mampu masuk ke darah otak atau terjadi mutasi pada satu atau beberapa tahapan kerja leptin (11).

Pada kondisi simpanan lemak berlebih, leptin diproduksi sebanding dengan tingginya simpanan energi dalam bentuk lemak. Leptin melalui sirkulasi darah mencapai hipotalamus, sedangkan a-MSH merupakan mediator alur hilirnya. Sintesis dan sekresi a-MSH oleh nukleus arkuatus hipotalami dikendalikan secara positif oleh ikatan antara leptin dengan reseptornya di badan saraf tersebut yang diikuti perubahan POMC menjadi a-MSH. Selanjutnya a-MSH menekan pusat lapar dan melalui sirkulasi darah ke perifer meningkatkan metabolisme dengan memacu lipolisis di jaringan adiposa (Gambar 1 (kiri)).

Pada kondisi simpanan lemak kurang setelah pembatasan asupan makanan dan pembakaran lemak karena aktifitas, leptin turun sehingga kadar a-MSH di hipotalamus berkurang. Keadaan ini memicu neuron pusat lapar di hipotalamus melepaskan agouti related protein (AGRP) yang sintesisnya di ditekan oleh leptin melalui ikatan dengan reseptornya. AGRP merangsang nafsu makan melalui mekanisme antagonis a-MSH terhadap 
MC4-R. Selanjutnya, pengurangan sintesis a-MSH dari POMC menekan katabolisme lemak sampai simpanan lemak di adiposit terisi kembali sebagai hasil kombinasi efek tersebut dengan perilaku makan. Bila simpanan lemak sudah cukup, mekanisme kontrol kembali ke penghambatan nafsu makan dan peningkatan penggunaaan energi sehingga berat badan dapat dipertahankan pada rentang terbatas bertahun-tahun (Gambar 1 (kanan)) (11).

\section{Pengendalian Efisiensi Energi}

Pengendalian efisiensi energi merupakan proses biokimiawi yang mengendalikan tingkat besarnya energi yang digunakan dari makanan. Tinggi rendahnya efisiensi metabolik berbeda antar individu dan komponen pengendalinya. Sifat ini secara genetik diwariskan (12). Kajian utama dalam pengendalian ini diarahkan pada pemanfaatan nutrisi melalui perubahan termogenesis dengan mediator uncoupling protein (UCP).

Termogenesis adalah pemanfaatan kandungan energi dalam makanan untuk pembentukan panas, di

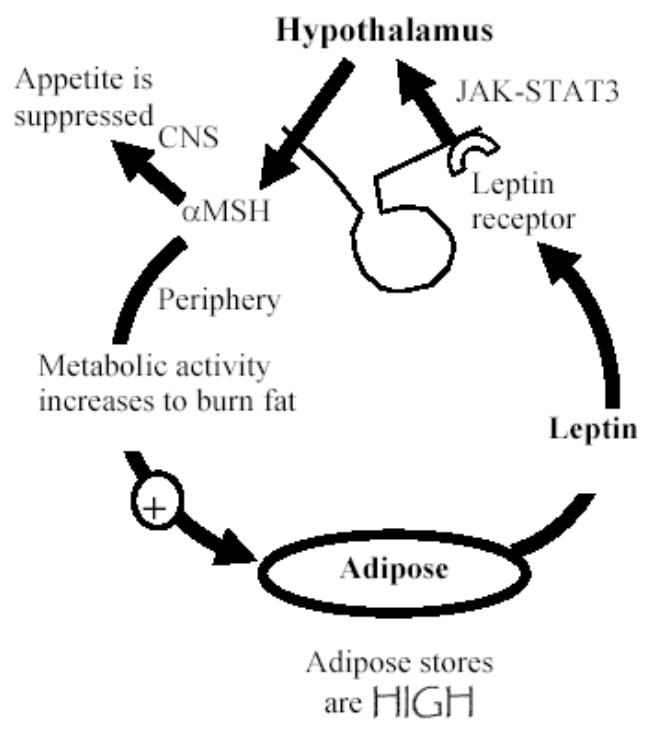

samping penimbunan dalam bentuk lemak di adiposit. Uncoupling protein tersebut mengendalikan penggunaan energi pada proses oksidasi di mitokondria dan ternyata ada kaitan antara obesitas dengan polimorfisme gen penyandi UCP. Kecenderungan peningkatan berat badan dan penurunan laju metabolisme istirahat berasosiasi dengan keberadaan satu dari dua allele utama gen penyandi UCP1 (13).

\section{Pengendalian Adipogenesis}

Pengendalian adipogenesis menghasilkan variasi karakteristik jaringan lemak antar individu. Variasi tersebut berupa hipertrofi yang pada umumnya didapatkan pada obesitas ringan, hiperplasi pada obesitas berat dan campuran keduanya pada obesitas sedang. Kajian tentang pengendalian adipogenesis ini berkaitan dengan konsep dasar diferensiasi dan ekspresi gen adiposit. Beberapa penelitian telah mengidentifikasi faktor transkripsi pendukung adipogenesis, antara lain PPARy dan C/EBP (14).

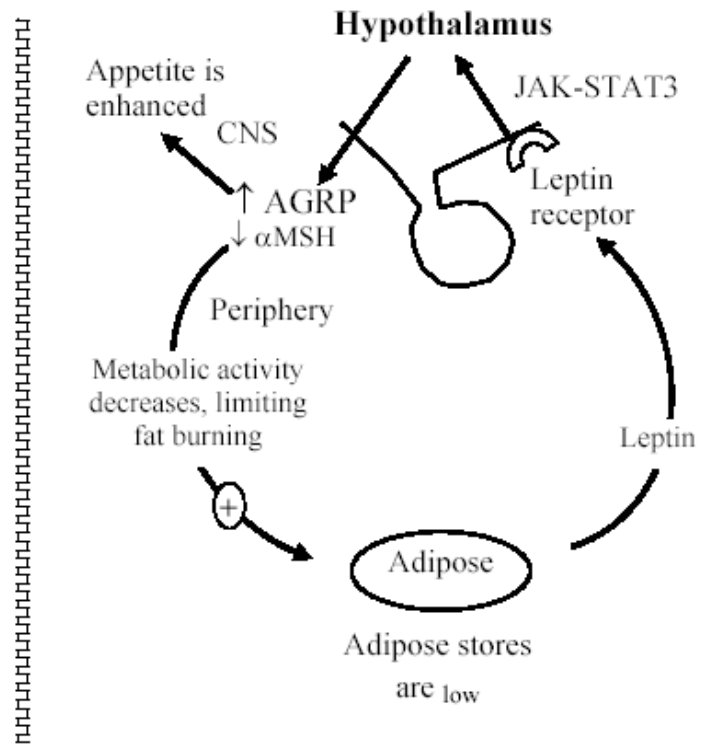

Gambar 1.Sistem sinyal leptin dan efeknya pada kondisi simpanan lemak di adiposit tinggi dan rendah (Dikutip dari Neuroendocrinology:Obesity. Tischler, 2004) (15) 


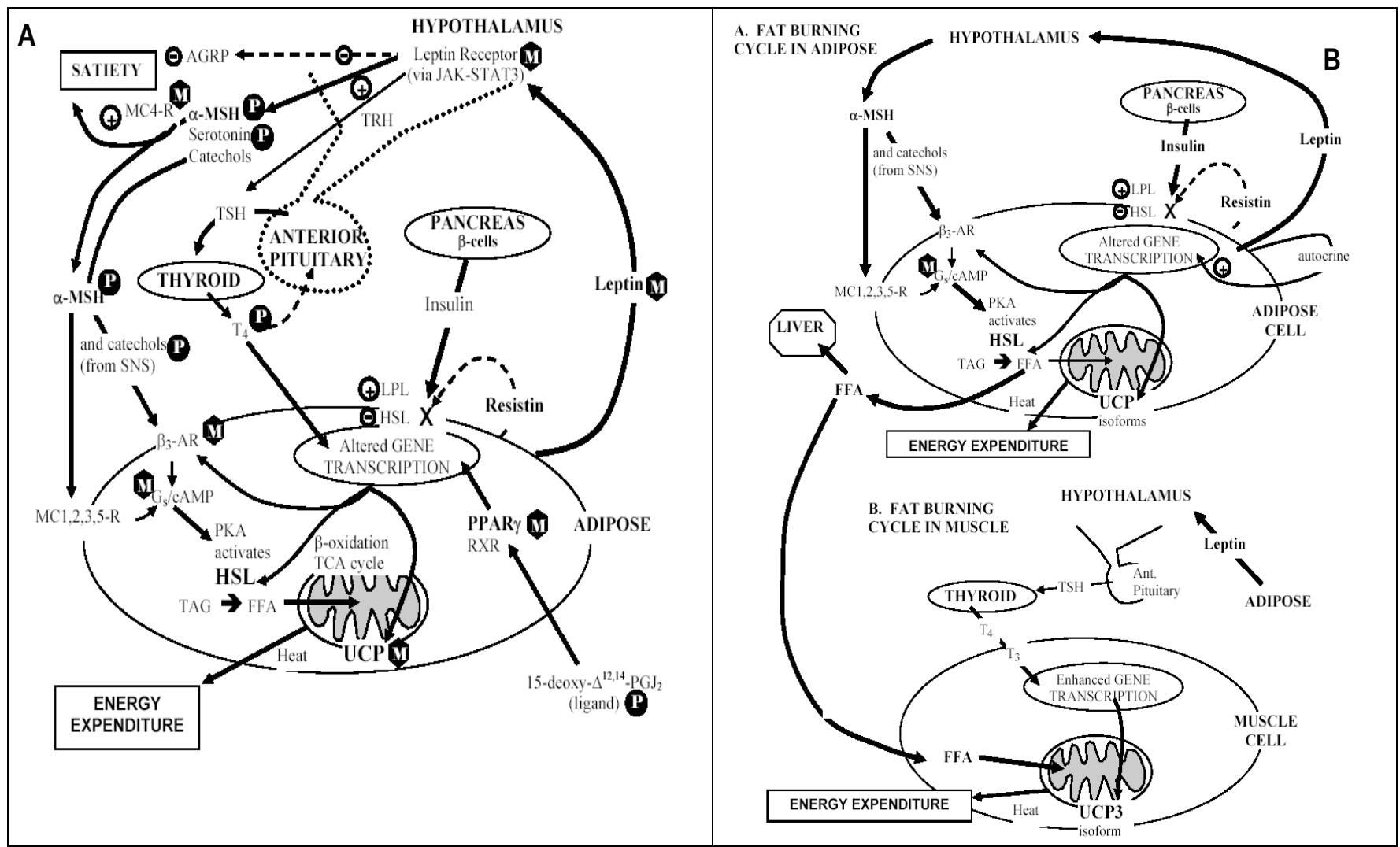

Gambar 2. Model pengendalian berat badan manusia terintegrasi. Simbol "M" dalam heksagonal menunjukkan situs mutasi penyebab obesitas, sedangkan "P" dalam lingkaran menunjukkan tahapan dimana obat antiobesitas sedang diujicobakan. Gambar (A) Siklus pembakaran lemak di adiposit dan (B) Siklus pembakaran lemak di otot (Dikutip dari Neuroendocrinology:Obesity. Tischler, 2004) (15)

\section{Peroxisome Proliferator Activated Peptide Receptor Gamma (PPAR-Gamma)}

Peran reseptor ini dalam obesitas ditunjang oleh keberhasilan penggunaan thiazolidinedione untuk pengobatan obesitas visceral. Obat ini juga dikenal sebagai glitazon yang berikatan dengan reseptor PPAR y dengan akibat peningkatan sensitifitas terhadap insulin disertai perubahan metabolisme lemak termasuk reduksi asam lemak bebas melalui peningkatan asupan di jaringan perifer dan subkutan. PPAR $y$ adalah reseptor inti yang penting dalam adipogenesis dan insulin signalling (14).

Mutasi Pro12Ala biasa terjadi dan menyebabkan penurunan kemampuan berikatan dengan PPAR Y responsive gene. Efek mutasi ini terhadap Indeks Massa Tubuh (IMT) bervariasi tetapi tampaknya efek yang terbesar terjadi pada individu berpredisposisi obese (16). Individu dengan mutasi Trp64Arg pada ADRB3 jauh lebih mudah obese bila juga mengalami mutasi Pro12Ala pada reseptor PPAR y nya (17).

\section{Receptor Beta3-Adrenergic (ADRB3)}

Receptor $\beta 3$-adrenergic pada manusia terutama diekspresikan di adiposit sekitar traktus gastrointestinal. Receptor $\beta 3$-adrenergic ini berperan dalam pengaturan lipolisis dan termogenesis (Gambar 2). Mutasi missense Trp64Arg pada gen ini banyak ditemukan pada suku Pima Indian dan berasosiasi dengan obesitas, sehingga diduga meningkatkan peluang kegemukan. Interaksi reseptor ini dengan reseptor lain mungkin mempengaruhi kemampuan reseptor ini dalam berinteraksi dengan mediatornya yaitu protein-G (18).

\section{Obesitas Monogenik}

Gen obesitas yang pertama kali ditemukan adalah Ob-gen. Kerusakan genetik yang pertama kali dideskripsikan dan diklonkan adalah gen pembentuk tikus kuning obese. Dua tikus model yang paling sering dipelajari, tikus obese dan tikus diabetes, ditemukan mengalami gangguan pada produksi circulating factor yang disebut leptin (ob/ob) dan reseptor leptin (db/db) (19).

Riset obesitas monogenik masih mengarah pada mutasi kandidat gen yang terkait dengan homeostatis energi. Beberapa mutasi gen yang diperkirakan sebagai penyebab monofaktorial obesitas antara lain: leptin, reseptor leptin, Pro-opiomelanokortin (POMC) dan reseptormelanokortin4 (MC4R). Pemberian leptin rekombinan berhasil menurunkan asupan makanan, mengembalikan rasa kenyang dan menurunkan massa lemak tubuh tanpa mengurangi massa non-lemak. Mutasi pada sistem ini 
jarang terjadi tetapi dapat mengakibatkan obesitas. Meskipun defisiensi leptin menyebabkan obesitas, dewasa ini diketahui bahwa obesitas pada umumnya ditandai oleh hiperleptinemia yang kemungkinan disebabkan resisten terhadap leptin. Dalam perkembangan riset selanjutnya, ditemukan bermacam-macam sindrom obesitas yang belum diketahui gen penyebabnya (20).

Faktor-faktor eksternal yang diproses di otak mempengaruhi pusat-pusat di hipotalamus yang selanjutnya menghasilkan sinyal lapar atau kenyang. Pada Gambar 3, jalur lapar (mengikuti panah tebal searah jarum jam) dimulai dari cortex cerebri kemudian menginisiasi sinyal lapar NP-Y dan AGRP. Pengikatan AGRP pada MC4-R bersifat antagonis sehingga menghambat kenyang dan merangsang nafsu makan. Pusat lapar di hipotalamus secara fisiologis selalu dalam keadaan "on" sampai ada inhibisi dari nukleus arkuatus yang bersinap melalui paraventricula nuclei (PVN)/ventromedial nuclei (VMN). Asupan makanan memicu nervus vagus dan pelepasan CCK-PZ dan GLP-1 sebagai impuls kenyang akut ke otak.

Sinyal pasca makan yang lebih kuat dan jangka panjang adalah insulin (disekresi oleh sel $\beta$ ), yang memicu penyimpanan energi melalui aktifasi LPL dan inhibisi HSL. Faktor kedua adalah leptin yang disintesis oleh jaringan adiposa putih (WAT) sebagai respons atas penimbunan lemak. Leptin mengumpan balik ke hipotalamus dengan menekan sinyal lapar antara lain AGRP, NP-Y dan galanin, dan sekaligus merangsang sinyal kenyang antara lain aMSH dan CART. $\alpha$-MSH melengkapi umpan balik lapar melalui ikatannya dengan MC4-R. Corticotropin releasing hormone $(\mathrm{CRH})$ dari hipotalamus yang sekresinya dipicu oleh leptin, merangsang sintesis POMC dan mencetuskan kaskade katabolik yang diawali dari saraf simpatis dan berakhir pada mobilisasi dan pembakaran lemak, serta penekanan sekresi insulin dari pankreas. Jaringan adiposa coklat (BAT) adalah sumber panas kedua setelah otot rangka terutama dalam pembakaran asam lemak bebas. Dengan demikian dapat disimpulkan bahwa leptin adalah hormon yang diproduksi jaringan adiposa putih dan merupakan mediator dominan dalam homeostatis penyimpanan lemak melalui sentral lipostat di hipotalamus. Mekanisme ini menghasilkan pengendalian yang disebut adipostat dan mirip kerjanya dengan thermostat (21).

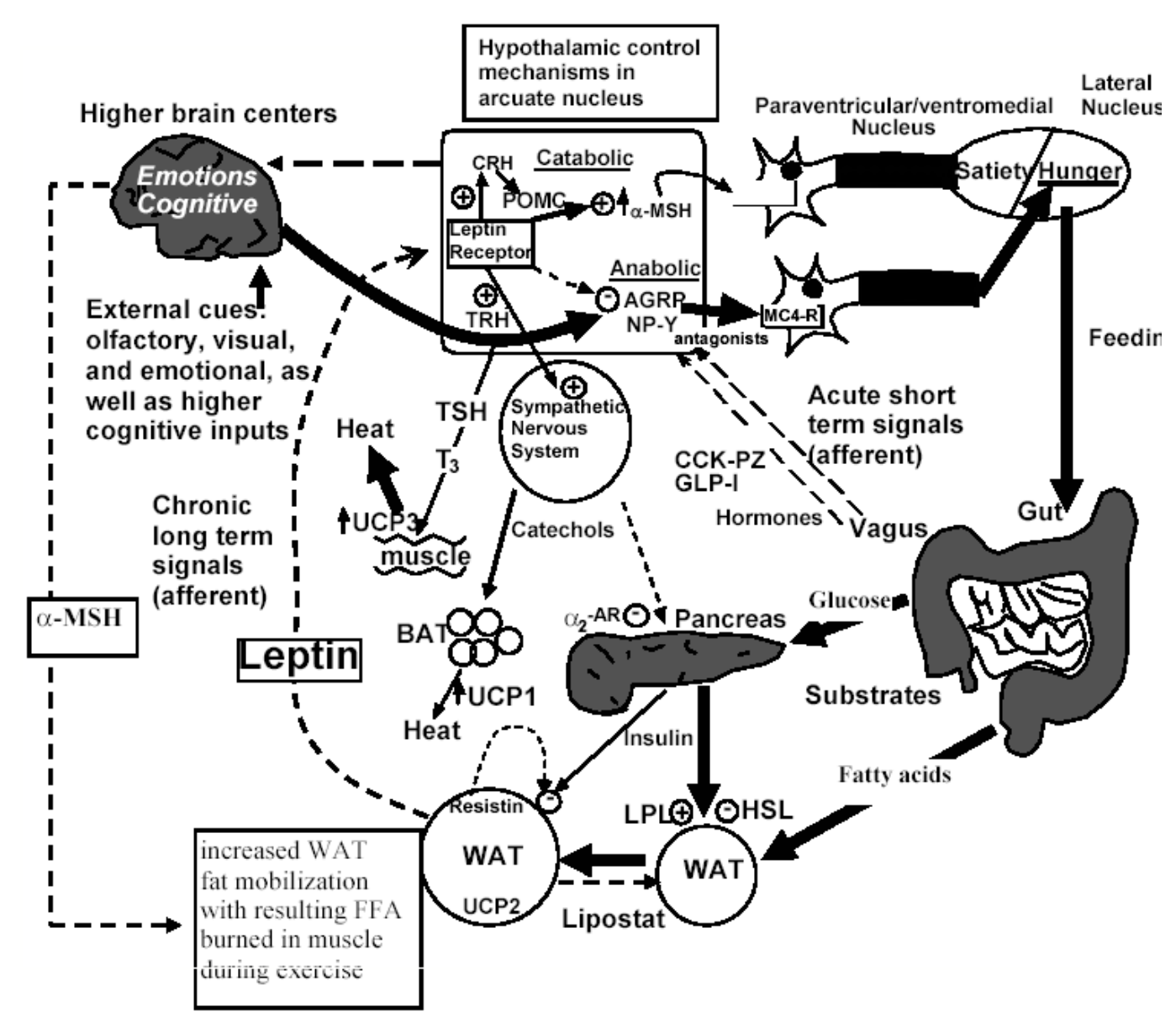

Gambar 3. Diagram pengendalian nafsu makan dan berat badan (Dikutip dari Neuroendocrinology:Obesity. Tischler, 2004) (15) 


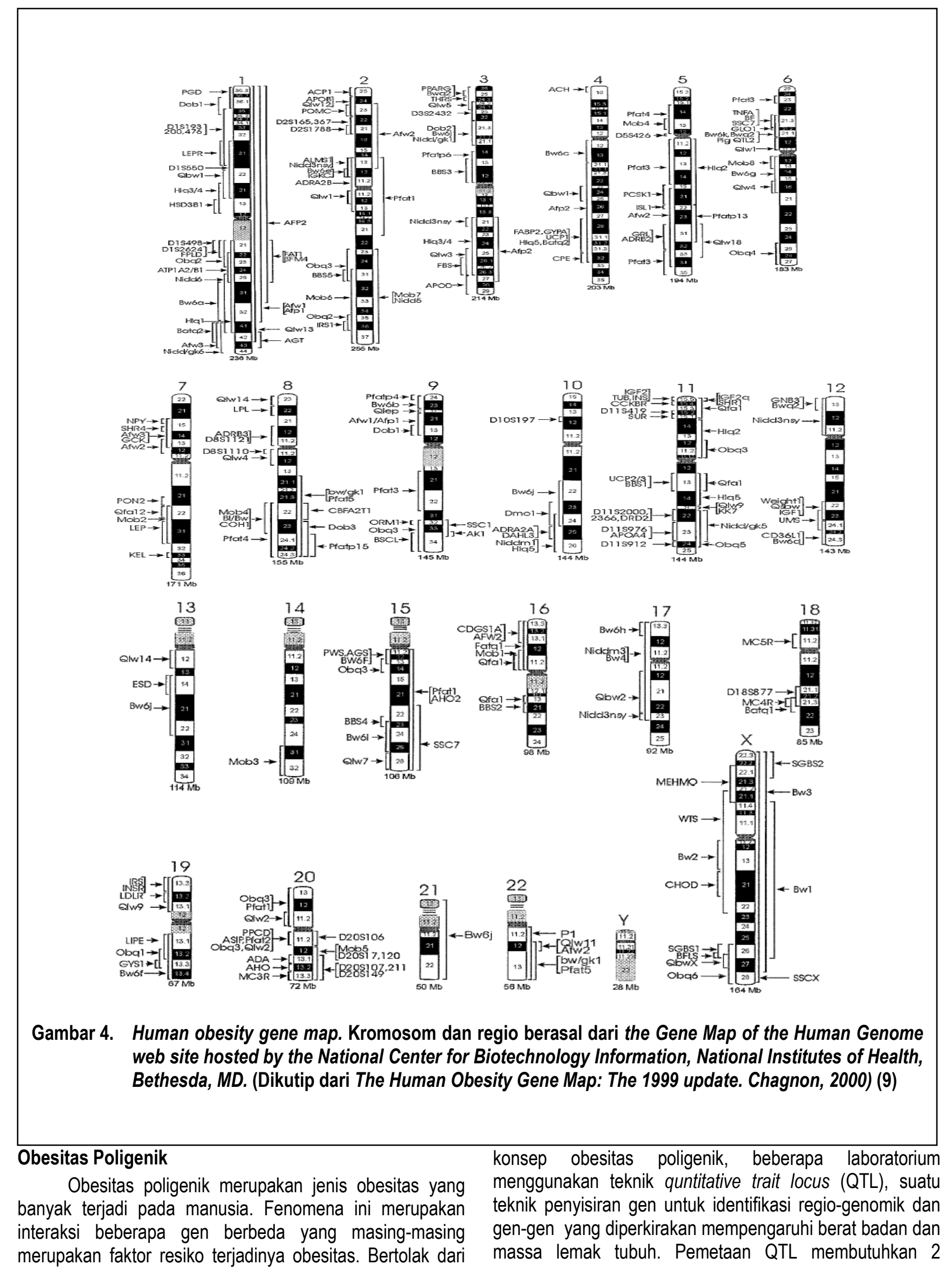


sumber utama, yaitu: dua strain inbreed dan peta genetik terinci dari genom hewan. Dua strain inbreed yang berbeda fenotipnya disilangkan untuk mendapatkan F1, kemudian F2 atau keturunan back-cross / silang-balik. Hewan diidentifikasi genotipnya secara individu untuk petanda kemudian ditentukan fenotipnya secara tepat. Lokus genom ditentukan secara interval mapping menggunakan perangkat lunak Mapmaker. Program ini menggunakan genetic marker dan quantitative phenotypes untuk mengidentifikasi QTL dengan LOD scoring (22).

Ada dua pendekatan yang dilakukan untuk mendeteksi gen-gen yang mendasari patogenesis obesitas pada manusia (22):

1. Pendekatan pertama difokuskan pada kandidat gen yang diduga berperan pada patogenesis obesitas berdasarkan pengetahuan tentang peran gen tersebut dalam homeostatis energi. Pendekatan ini menghasilkan temuan kandidat gen baru melengkapi temuan dari pendekatan monogenik, antara lain gen penyandi: receptor $\beta 3$ - adrenergic, uncoupling protein $(\mathrm{UCP})$, lipoprotein lipase (LPL), protein kinase $A(P K A)$ dan tumor necroting factor alpha (TNF-a).

2. Penyisiran genomik yang luas pada kumpulan keluarga-keluarga etnis dan ras tertentu untuk mendeteksi regio kromosom yang menunjukkan keterkaitan dengan obesitas.

Beberapa penelitian yang telah memberi sumbangan besar dalam pengembangan konsep poligenik obesitas antara lain hasil penyisiran nuclear family di Meksiko, Perancis, suku Indian Pima dan keluarga kulit putih Amerika.

Di antara kompleks pembawa sifat (traits) pada individu manusia, adipositas merupakan salah satu sifat yang paling mudah terwariskan. Beberapa lokus utama saja sudah cukup memberi resiko genetik obesitas.

\section{PENUTUP}

Pengetahuan tentang gen dan molekul yang berperan dalam proses biokimiawi dan proses lain yang berdampak pada terjadinya obesitas meningkatkan pemahaman molekuler sistem pengendali berat badan dan membuka jalan metode baru pengendalian obesitas baik secara farmakologis maupun intervensi nutrisional bahkan mungkin juga genetik.

Pedoman baku dalam praktek sehari-hari belum dapat diterapkan pada bidang baru ini tanpa pemahaman model yang tepat untuk pemberian konsultasi pada pasien yang diduga memiliki faktor keturunan. Pemandu diet seyogyanya membekali diri dengan terminologi dan pengetahuan terkini dan praktisi di seluruh bidang nutrisi wajib memprioritaskan belajar berkesinambungan tentang genetika manusia untuk mempertahankan profesionalismenya.

\section{DAFTAR KEPUSTAKAAN}

1. Bjorntorp P. Thrifty Genes an Human Obesity. Are we Chasing Ghosts?. Lancet 2001; 358:1006-1008.

2. Levin and Patterson* News \& View. Exercising the obese brain: Resetting the defended body weight. Endocrinology 2005;146:1674-1675.

3. Chakravarthy MV, Booth FW. Eating, Exercise, and "thrifty" Genotypes: Connecting the Dots Toward an Evolutionary Understanding of Modern Chronic Diseases. J Appl Physiol 2004; 96: 3-10.

4. WHO Expert Consultation. Appropriate Body Mass-Index for Asian Population and Its Implications for Policy and Intervention Strategies. Lancet 2004;363:157-163.

5. Booth ML, Chey T, Wake M et al. Change in the Prevalence of Overweight and Obesity Among Young Australian, 1969-1997. Am J Clin Nutr 2003;77: 29-36.

6. Law CM, Barker DJ, Osmond C, Fall CH, Simmond SJ. Early Growth and Abdominal Fatness In Adult Life. J Epidemiol Community Health 1992;46:184-186.

7. Liu YJ, Xu FH, Shen H. et al. A Follow-Up Linkage Study for Quantitative Trait Loci Contributing to Obesity-Related Phenotypes. J Clin Endocrinol Metab 2004; 89: 875-882.

8. Comuzzie, Anthony G. The Genetics of Obesity in Mexican Americans: The Evidence from Genome Scanning Efforts in the San Antonio Family Heart Study. Human Biology. 2003; 75(5): 635-646.

9. Chagnon YC, Snyder EE, Walts B, Pe'russe L, Weisnagel SJ, Rankinen T, and Claude Bouchar. The Human Obesity Gene Map: The 2003 Update. Obesity Research. 2004; 12(3): 369-439.

10. Proietto J, Baur LA. 10: Management of Obesity. Med J Aust 2004;180:474-480.

11. Clement K, Garner C, Harger J, Philippi A, LeDuc C, Carcy A, Harris TJ, Jury C, Cardon LR, Basdevant A, Demenais F, Guy-Grand B, North M, Froguel P. Indication for Linkage of The Human Ob Gene Region With Extreme Obesity. Diabetes 1996;45:687-690.

12. Bouchard C. Currentunderstanding of Aetiology of Obesity Genetic and Non-Genetic Factors. Am J Clin Nutr 1991; 53:1561-1565. 
13. Oppert JM, Vohl MC, Chagnon M, Dionne FT, Cassad-Doulcier AM, Ricquier D, Perusse L, Bouchard C. DNA Polymorphism in the Uncoupling Protein (UCP) Gene and Human Body Fat. Int J Obes Relat Metab Disord 1994;18:526-531.

14. Wu Z, Rosen ED, Brun R, Hauser S, Adelmant G, Troy AE, McKeon C, Darlington GJ, and Spiegelman BM. CrossRegulation of C/EBP _ and PPAR _ Controls the Transcriptional Pathway of Adipogenesis and Insulin Sensitivity. Mol. Cell. 1999;3: 151-158.

15. Tischler. Neuroendocrinology:Obesity. Lecture 2004; 52:1-12.

16. Deeb SS, Fajas L, Nemoto M, Pihlajamaki J, Mykkanen L, Kuusisto J, Laakso M, Fujimoto W, Auwerx J. A Pro12Ala Substitution in PPAR2 Associated with Decreased Receptor Activity, Lower Body Mass Index and Improved Insulin Sensitivity. Nat Geet 1998; 20: 284-287.

17. Hager J, Clement K, Francke S, Dina C, Raison J, Lahlou N, Rich N, Pelloux V, Basdevant A, Guy-Grand B, North, M, Froguel P. A Polymorphism in the 5[prime]-untranslated Region of the Human Ob Gene is Associated with Low Leptin Levels. Int J Obes Relat Metab Disord 1998; 22: 200-205.

18. Clement K, Vaisse C, Manning BS, Basdevant A, Gyu-Grand B, Ruiz J, Silver KD, Suldiner AR, Froguel P, Strosberg AD. Genetic Variation in the $\beta 3$-adrenergic Receptor Gene and an Increased Capacity to Gain Weight in Patients with Morbid Obesity. N Engl J Med. 1995; 333: 352-354.

19. Zhang YY, Proenca R, Maffei M, Barone M, Leopold L, and Friedman JM. Positional Cloning of The Mouse Obese Gene and Its Human Homolog. Nature 1994; 372: 425-432.

20. Faroogi IS, Jebb SA, Langmack G, Lawrence F, Cheetham CH, Prentice AM, Hughes IA, Mc Camish MA, O'Rahilly S. Effects of Recombinant Leptin Therapy in a Child With Congenital Leptin Deficiency. N Engl J Med. 1999; 341:879884.

21. Lander ES, and Botstein D. Mendelian Factors Underlying Quantitative Traits Using RFLP Linkage Maps. Genetics. 1989; 121: 185-199.

22. Froguel P and Boutin P. Genetic of Pathways Regulating Body Weight in The Development of Obesity in Humans. Exp Biol Med. 2001;226(11):991-996. 

Indra, Dasar Genetik Obesitas....... 19 